\title{
Gastroprotective Activity of Olive Leaves Extract on 2,3,7,8 Tetrachlorodibenzo-p-dioxin induced Gastric Fundic Mucosal Injury in Adult Male Albino Rats (Light and Electron Microscopic Study)
}

\author{
Marwa Salah
}

Department of Zoology, Faculty of Science, Beni-Suef University, Beni-Suef, Egypt

\begin{abstract}
Background: 2,3,7,8-Tetrachlorodibenzo-p-dioxin (TCDD) is one of the most toxic artificial chemicals present in the environment. TCDD exposure is associ $\neg$ ated with stomach damage. Olive leaves extract (OLE) is a herbal agent, used in medication with a variety of beneficial therapeutic effects.

Objective: To evaluate the protective effect of OLE against TCDD induced fundic mucosal damage in adult male albino rats. Materials and Methods: Seventy rats were divided into 3 groups: Group I (control group), group II (TCDD group): these rats received TCDD $(100 \mu \mathrm{g} / \mathrm{kg}$ body weight/day) orally for 8 weeks, group III (TCDD and OLE group): rats of this group received TCDD and OLE ( $0.5 \mathrm{~g} /$ body weight/day) orally for 8 weeks. Specimens from the gastric fundus were excised and stained with H\&E and Periodic acid Schiff(PAS) for both routine histological and histochemical studies, and immunohistochemically for the detection of chromomgranin A. Morphometric and electron microscopic studies were also carried out.

Results: TCDD induced mucosal injury, sloughing of surface mucosal cells, areas of gastric ulcer, glandular disarrangement, and decreased mucosal height, as well as a decrease in the PAS and chromogranin A positive reactions. Electron microscopic studies showed deteriorating changes in parietal cells, chief cells, mucous cells, and enteroendocrine cells. In contrast, most of the changes induced by TCDD were not observed in TCDD and OLE-treated group.

Conclusion: TCDD has toxic effects on the histological and ultrastructure of fundic mucosa of rats, and OLE decreased these effects. OLE can be used to avoid TCDD-induced gastric complications.
\end{abstract}

Received: 21 December 2019, Accepted: 07 March 2020

Key Words: Gastric fundus, histology, olive leaves extract, TCDD, ultrastructure.

Corresponding Author: Marwa Salah, PhD, Zoology Department, Faculty of Science, Beni-Suef University, Beni-Suef 62514, Egypt, Tel.: +20 1158066236,E-mail: marwa_salah78@yahoo.com

ISSN: 1110-0559, Vol. 43, No.4

\section{INTRODUCTION}

Advancing technology and industry have brought biochemical contamination with them. While numerous toxic matters have sound effects on the living organisms and environment, dioxins and dioxin like compounds are among the most commonly encountered and have high toxicity. Dioxins are released into the environment by several industries; including agricultural, paper, and chemicals industries, and the primary sources of environmental dioxin are combustion and incineration processes ${ }^{[1]}$. Practically all humans are frequently exposed to dioxins through ingestion, dermal contact, or inhalation. Contaminated food is a major source of dioxins consumption in human ${ }^{[2]}$. Fats, milk, milk products, and fishes are the main sources of food dioxins ${ }^{[3]}$.

The health threat due to extensive exposure to dioxins in humans has been stated by some researchers ${ }^{[4]}$. Cadiotoxicity, nerve illness, tumorigenesis effect, reproductive dysfunction and immune system defect have been recorded as adverse effects to human and animal bodies due to polychlorinated biphenyls and dioxins ${ }^{[5]}$.
The main and best examined dioxin compound is the $2,3,7,8$ tetrachlorodibenzo-p-dioxin (TCDD) which is highly toxic; it is consequently considered as a reference for evaluating the toxic effect of other compounds related to this group ${ }^{[6]}$. Its half-life in the human body is long (6-8 years) due to its high stability and lipophilic nature ${ }^{[7]}$. TCDD accumulate in liver adipose tissue leading to various health problems ${ }^{[8]}$. It has been proved that oxidative stress is a significant contributor to the TCDD toxicity ${ }^{[9]}$.

Up to $63 \%$ of TCDD content in foods is absorbed primarily through the upper part of gastrointestinal tract, like the duodenum and $\operatorname{stomach}^{[10]}$. So, the gastrointestinal tract is exposed to high concentration of dioxins ${ }^{[11]}$. However, little information has been published on the effect of dioxins on the gastrointestinal tract.

Recent studies on the management of gastrointestinal syndrome have focused on the protective effect of natural medicine because they are available, better protective, low cost, and low toxic ${ }^{[12]}$. Several antioxidant compounds, naturally arising from plant sources, have been recognized 
as free radical scavengers ${ }^{[13]}$. Natural antioxidants protect the body from free radicals and delay the progress of several chronic disease ${ }^{[14]}$. Polyphenols as antioxidants may inhibit or decrease oxidative stress at cellular levels, caused by imbalance between reactive oxygen species (ROS) and cellular antioxidants ${ }^{[15]}$.

Olive leaves as a rich source of polyphenolic compounds have better antioxidant, anti-inflam-matory, antihypertensive, anticancer, antimicrobial, gastroprotective, anti-atherosclerotic, antidiabetic, wound healing, and radical scavenging effects ${ }^{[16-20]}$. Olive leaves as an early medication were used as herbal tea or extract in Europe and the Med-iterranean diet. Several phenolics in olive leaves have strong radical scavenging property and the olive phenolics mixture, as olive leaves extract (OLE), display more useful than isolated as a single phenolic composite. OLE has a synergistic ability in the free radicals elimination that is more superior to the antioxidant ability of the vitamin $\mathrm{E}$ and $\mathrm{C}^{[21]}$.

Therefore, the present study aimed at evaluating the protective effects of OLE on the histology and ultrastructure of the fundic mucosa of adult male albino rats exposed to TCDD.

\section{MATERIALS AND METHODS}

\section{Animals}

Adult male albino rats (Rattus norvegicus) weighing (150-170g), were purchased from the animal house of the Research Institute of Ophthalmology, El-Giza, Egypt. Animals were kept in the animal facility of the Faculty of Science, Beni-Suef University, fed a standard diet and water ad libitum. Rats were kept under controlled conditions of temperature $\left(20 \pm 0.5^{\circ} \mathrm{C}\right)$ and relative humidity $(55 \pm 5)$ with $12 \mathrm{~h}$ dark/light cycle. The handling of the animals was done according to the international guidelines concerning animal experiment.

\section{Used reagents}

2,3,7,8 tetrachlorodibenzo-p-dioxin (TCDD) was obtained from Sigma Company (Sigma Chemical Co., Sigma-Aldrich Ltd., Poland). Stock solutions were prepared by adding $10 \mu \mathrm{g}$ of TCDD to $1 \mathrm{ml}$ of corn oil and acetone (at a ratio of 99:1) to prepare the dosing solutions and were kept at $-200 \mathrm{C}$ till use.

\section{Plant Extract Preparation}

Fresh matured olive leaves (Olea europaea) were collected from Al-Fayoum farms, Al-Fayoum Government, Egypt. The leaves were identified by Dr. Fadl M (a specialized taxonomist in Botany Department, Faculty of Science, Beni-Suef University, Egypt). Leaves were washed, dried and homogenized into fine powder $(50 \mathrm{~g})$. The powder was soaked with $500 \mathrm{~mL}$ of $70 \%$ ethanol $(1 / 10$, w/v) for one week at room temperature ${ }^{[22]}$. The remaining extract was filtered using a $0.45 \mu \mathrm{m}$ Whatman filter paper then evaporated. A weighed portion of the extract was dissolved in distilled water and given orally by intragastric tubes at a dose of $0.5 \mathrm{~g} / \mathrm{kg}$ body weight ${ }^{[23]}$.

\section{Experimental design}

A total of 70 rats were classified into three experimental groups:

Group I (Control group): Animals of this group were further subdivided into three subgroups each one included ten rats.

- Subgroup IA: The normal control group which received distilled water orally and daily for 8 weeks.

- Subgroup IB: Rats received corn oil (vehicle for TCDD) orally and daily for 8 weeks.

- Subgroup IC: Rats received only olive leaves extract (OLE) daily at an oral dose of $0.5 \mathrm{~g} / \mathrm{kg}$ body weight $^{[23]}$ for 8 weeks.

Group II (20 rats): The TCDD treated group at a daily oral dose of $100 \mu \mathrm{g} / \mathrm{kg}$ body weight $\mathrm{TCDD}^{[24]}$ for 8 weeks.

Group III (20 rats): TCDD+ OLE at the same dose and period of group II and subgroup IC.

At the end of the experiment, the rats were sacrificed and their stomach were dissected out, washed with saline, and cut along their greater curvatures. Samples from the fundus part of stomach were prepared for light and electron microscopic investigation.

\section{Processing of specimens}

\section{Light microscopic study}

Stomach specimens from the fundus part of the stomach were fixed in $10 \%$ neutral buffered formalin solution overnight. Tissue samples were dehydrated, cleared, and embedded in paraffin. Paraffin sections ( $5 \mu \mathrm{m}$ thickness) were processed and stained with hematoxylin and eosin stains to confirm histological details, and Periodic Acid-Schiff technique (PAS) for histochemical detection of mucin ${ }^{[25]}$.

\section{Immunohistochemical investigation of chromogranin $A$}

chromogranin A immunohistochemical reaction was done by the avidin-biotin complex immunoperoxidase system $^{[26]}$. Sections from paraffin embedded stomach samples were deparaffinized on charged glass slides. The sections were incubated in $0.1 \%$ hydrogen peroxide (30 minutes) to block the endogenous peroxidase and incubated with the primary antibody (chromogranin A antibody). The primary antibody used for chromogranin A was a ready to-use rabbit polyclonal antibody (CAT-No. RB-9003-R7; Thermoscientific Laboratories, Rockford, IL, USA). The slides were then incubated with the secondary anti-rabbit antibody versal kits (Zymed laboratories) diluted 1:200 for 30 minutes. Staining was finalized by incubation with diamiobenzidine (DAB) as a chromogen, which give rise to brown colored at the sites of antigen. Mayer's hematoxylin was used as a counterstain. In negative control, phosphate buffer solution was used instead of the primary antibody. Lastly, chromogranin A immunohistochemical expression appeared in the cytoplasm as brown stain. 


\section{Electron microscopic study}

Specimens, from the fundus part of the stomach, for electron microscopic study were collected and immediately fixed in $2.5 \%$ glutaraldehyde in $0.1 \mathrm{M}$ phosphate buffer (pH 7.4) at $4{ }^{\circ} \mathrm{C}$ for $2 \mathrm{~h}$. The tissue specimens were postfixed in $1 \%$ osmium tetroxide at $4^{\circ} \mathrm{C}$ for $2 \mathrm{~h}$, dehydrated in ethyl alcohol, cleared in propylene oxide then embedded in epoxy resin ${ }^{[27]}$. Semi-thin sections ( $1 \mu \mathrm{m}$ thickness) were cut by ultramicrotome (Leica Ultracut; Leica, Berlin, Germany), stained with toluidine blue, and examined by light microscope, for general orientation. Ultrathin sections $(70-90 \mathrm{~nm})$ were obtained and counterstained with uranyl acetate and lead citrate ${ }^{[28]}$, then examined by a JEOL JEM 10200 EXII electron microscope (Jeol Ltd, Tokyo, Japan) at the Faculty of Science, Ain Shams University, Egypt.

\section{Morphometric analysis}

The image analyzer computer system Leica Qwin 500 (Leica Ltd, Cambridge, UK), in the Histology and Cell Biology Department, Faculty of Medicine, Ain Shams University, Egypt, was used to measure the mucosal height, the area percentage (\%) of PAS positive reaction and the optical density of chromogranin-A immunoreactivity.

For measuring the height of gastric mucosa, the perpendicular distance between the mucosal surface and the muscularis mucosa were measured using the same histological sections $(5 \mu \mathrm{m})$ of the stomach used for histological evaluation. Gastric mucosal height was measured in four microscopic fields at a magnification of 400 (X400). In each field, the mucosal height was measured at five approximately equidistant points and was expressed as the average of twenty measurements for each rat.

The mean area percentage ( $\%)$ of PAS positive reaction and the optical density of chromogranin A immunoreactivity were evaluated from ten randomly selected non-overlapping fields at a total magnification of 400 (X 400).

\section{Statistical analysis}

All data were expressed as mean \pm standard error (mean \pm SE). Statistical analysis of data was performed by SPSS software, version 20 (SPSS Inc, Chicago) ${ }^{[29]}$. One way analysis of variance and post-hoc least significant difference were used to compare the variance between the groups. Values of $p>0.05$ were non-significantly different, while values of $p<0.05$ were considered significant.

\section{RESULTS}

\section{Histological Results}

\section{Light microscopic results}

\section{Hematoxylin and Eosin $(H \& E)$ stain}

Examination of the specimens taken from the control untreated group and OLE group showed the same histological architecture (Figures 1a-f).

Light microscopic investigation of the fundic mucosa of control untreated sections stained with hematoxylin and eosin (H\&E) revealed normal architecture of fundic glands, lamina propria, and muscularis mucosa (Figure 1a). Many fundic glands occupied the entire thickness of the mucosa. These glands extend from the lowermost part of the gastric pits to the layer of muscularis mucosa. They appeared perpendicular to the surface, looked straight and close to each other. They were three to four times as long as the gastric pits. Each gland was divided into isthmus, neck, and base (Figure1a). The gastric pits lined by surface mucous cells. The cells of isthmus and neck looked pale due to the dominance of parietal cells and mucous cells (Figure 1a). The bases appeared darker because of the prevalence of chief (peptic) cells (Figure 1a). The parietal cells were identified by their central nuclei and eosinophilic cytoplasm (Figure 1b). The mucous cells were found near the surface and also in the neck part of the glands (Figure 1b). Surface mucous cells appeared paler than chief cells. Their oval nuclei were basally located. The mucous cells of the neck part were scattered between parietal cells. Their nuclei appeared flat and basally located (Figure 1b). Chief cells had basophilic cytoplasm and basal nuclei (Figure 1c). OLE control group showed similar structure (Figures 1d-f).

H\&E stained sections of TCDD treated rats showed dispersed inflammatory cells, and dilated blood vessels (Figures 2a,b,c,e). Some glands appeared with lymphocytic aggregations (Figure 2a). Some sections showed severe mucosal damage and disturbed glandular construction (Figures 2c-g). Atrophic, disorganized, and widely separated fundic mucosal glands were also seen (Figures 2c,f,g). Moreover, the cells of the luminal surface and approximately all the cells of the gastric pits were lost. The damaged mucosal surface displayed desquamation of epithelial cells into the lumen (Figures 2b,c,f). Many glandular cells appeared with cytoplasmic vacuolations (Figures 2e-g). Some dilated gastric glands lined by flattened epithelial cells (Figure 2f). Few specimens displayed areas of gastric ulcer (Figure 2d).

H\&E stained sections from the fundic stomach of TCDD and OLE showed regular arrangement of fundic glands, relatively preserved mucosal cells and gastric pits (Figures 3a,b). The lamina propria had blood vessels of relatively normal size (Figure 3a). The fundic glands appeared with nearly normal mucous cells, parietal cells and chief cells (Figures 3b,c). Some parietal cells were observed with vacuolated cytoplasm (Figure $3 b$ ).

\section{PAS Stain}

PAS-stained sections of the control untreated group (Figure 4a) and OLE control group (Figure 4b) revealed strong PAS positive reaction in the surface cells of the mucosa and spread down to the gastric pits. The gastric cells showed weak PAS-positive reaction. Sections from TCDD-treated group showed weak PAS positive reaction when compared to the control groups (Figure 4c ). PAS stained sections of TCDD and OLE-treated group revealed a moderately normal PAS positive reactivity on the mucosal surface cells and extend down into the gastric pits as compared to TCDDgroup (Figure 4d). 


\section{Chromogranin A immunohistochemistry}

Strong brown positive chromogranin A immunoreactions were observed in the cytoplasm of chromogranin A secreting cells of control untreated (Figure 5a) and OLE control groups (Figure 5b). Weak positive chromogranin A immunoreactions were noticed in the cells of the TCDD-treated rats (Figure 5c). Moderate brown chromogranin A immunoreactions were seen in chromogranin A secreting cells of TCDD and OLE-treated rats as compared with control rats (Figure 5d).

\section{Histomorphometric results}

The mean mucosal height of the gastric fundic glands showed no significant change between the control subgroups. Though, significant decrease in the mean mucosal height was observed in the TCDD-treated rats in comparison to that of the control rats. The mean mucosal height was significantly increased in the OLE +TCDD-treated rats in comparison to that of the TCDD-treated rats (Histogram 1).

Morphometric analysis of the mean area percentage (\%) of the PAS positive reaction showed a significant decrease in TCDD-treated group as compared to the control subgroups. The mean area percentage ( $\%)$ of the PAS positive reaction showed a significant increase in TCDD+OLE group as compared to that of TCDD treated group (Histogram 2).

The mean optical density of chromogranin A expression in the fundic mucosa of TCDD treated group showed a significant decrease in comparison to the control subgroups and TCDD+OLE-treated group. On the other hand a significant increase in the mean optical density of chromogranin-A expression was noticed in the TCDD+OLE group in comparison to that of TCDD-treated group (Histogram 3).

\section{Electron microscopic results}

\section{Control group}

The parietal (oxyntic) cells of the control rats had rounded vesicular euchromatic nuclei with prominent nucleoli, various mitochondria were scattered all over the cytoplasm (Figure 6a), and intact tubulovesicular system. The chief (peptic) cells showed vesicular nuclei, parallel cisterns of rough endoplasmic reticulum and well developed Golgi apparatus. Variable-sized electron lucent zymogen granules at the apical part of the cell were also noticed (Figure 6b). Mucous cells had many electron lucent mucous granules and euchromatic nuclei (Figure 6c). The enteroendocrine cells are found at the bases of the glands. Their cytoplasm contains small electron dense secretory granules at the basal part, and large euchromatic nuclei (Figure 6d).

\section{TCDD group}

The parietal cells revealed degenerative changes. It showed few dense mitochondria, cytoplasmic vacuolations, and dilated tubulovesicular system (Figures 7a,b) Some parietal cells had irregular nuclei with condensed chromatin (Figure 7d). The chief cells contained a few cytoplasmic secretory granules, dilated rough endoplasmic reticulum, Golgi saccules and shrunken condensed nuclei (Figure 7c). The mucous cell showed irregular nucleus and groups of empty and fused cytoplasmic vesicles with an altered cell surface (Figures 7b,d). Enteroendocrine cells showed irregular and pyknotic nuclei, vacuolated cytoplasm, and numerous small electron dense secretory granules (Figure 7e).

\section{TCDD and olive leaves extract group}

Many parietal cells appeared with euchromatic nuclei, various mitochondria, and intact tubulovesicular system (Figure 8a). Chief cells contained regular euchromatic nuclei, slightly dilated or regularly arranged rough endoplasmic reticulum and electron lucent secretory granules (Figures 8b,d). Mucous secreting cells revealed euchromatic nuclei and many secretory granules with variable density (Figure 8c). Enteroendocrine cells showed many small electron dense secretory granules and irregular nuclei (Figure 8d). 

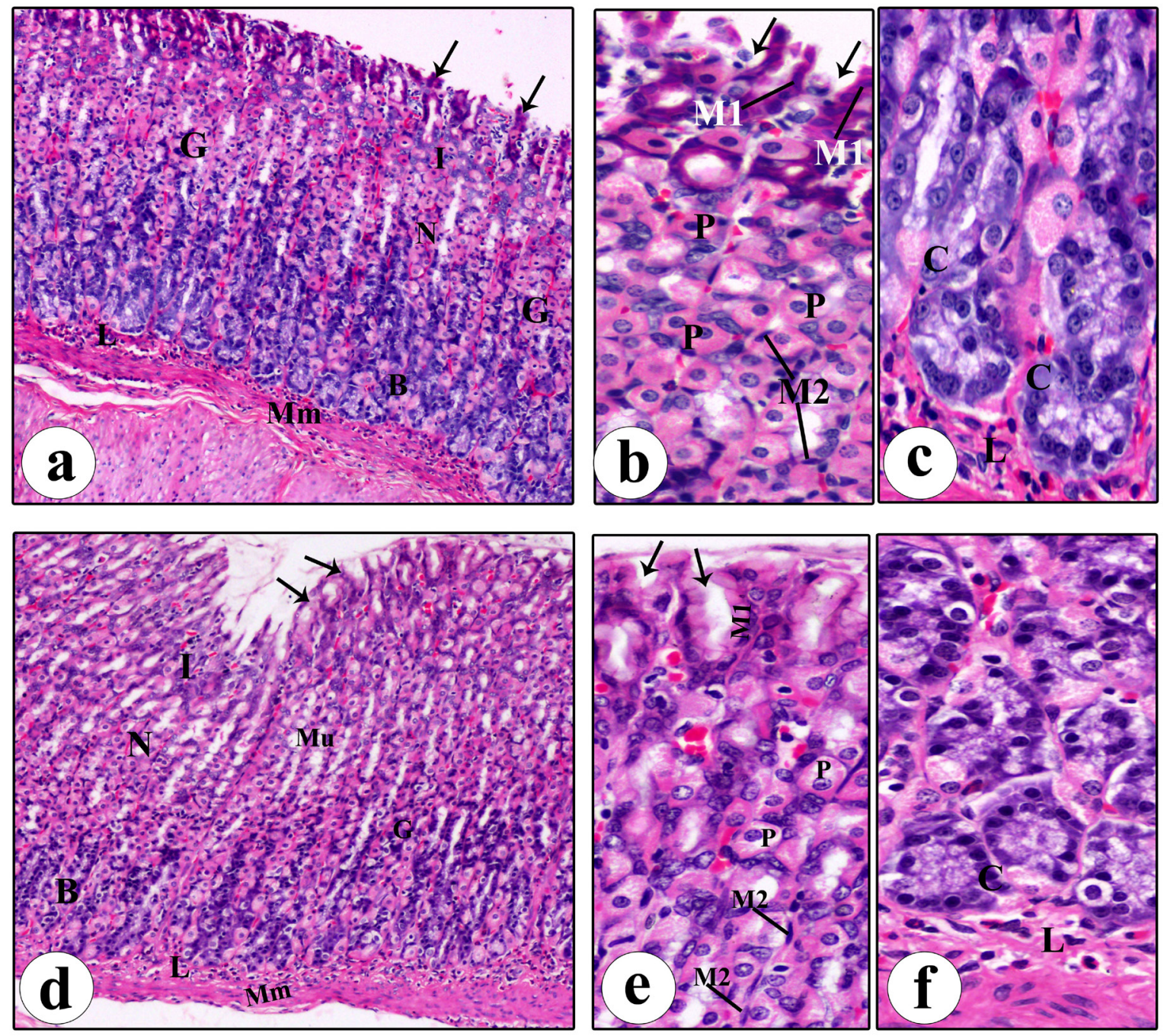

Fig. 1: Light micrographs of the fundic stomach of (a-c) control untreated rat and (d-f) OLE control rat showing a,d) fundic glands (G), lamina propria (L), and muscularis mucosa (Mm). The fundic glands seemed narrow, long, regular and perpendicular to the luminal epithelium (arrows). The gland divides into isthmus (I), neck (N) and base (B). b,e) the apical part of fundic mucosal glands lined by surface mucous cells (M1) and parietal cells (P) with their central vesicular nuclei and eosinophilic cytoplasm. Note the mucous neck cell with flat and basally located nuclei (M2). The gastric pits (arrows) are seen. 1c,f) The basal part of fundic glands showing chief cells (C) with basal nuclei and basophilic cytoplasm giving the gland a darker appearance. Note a part of the lamina propria is seen (L). (H\&E; a,d X 100, b,c,e,f X 400) 

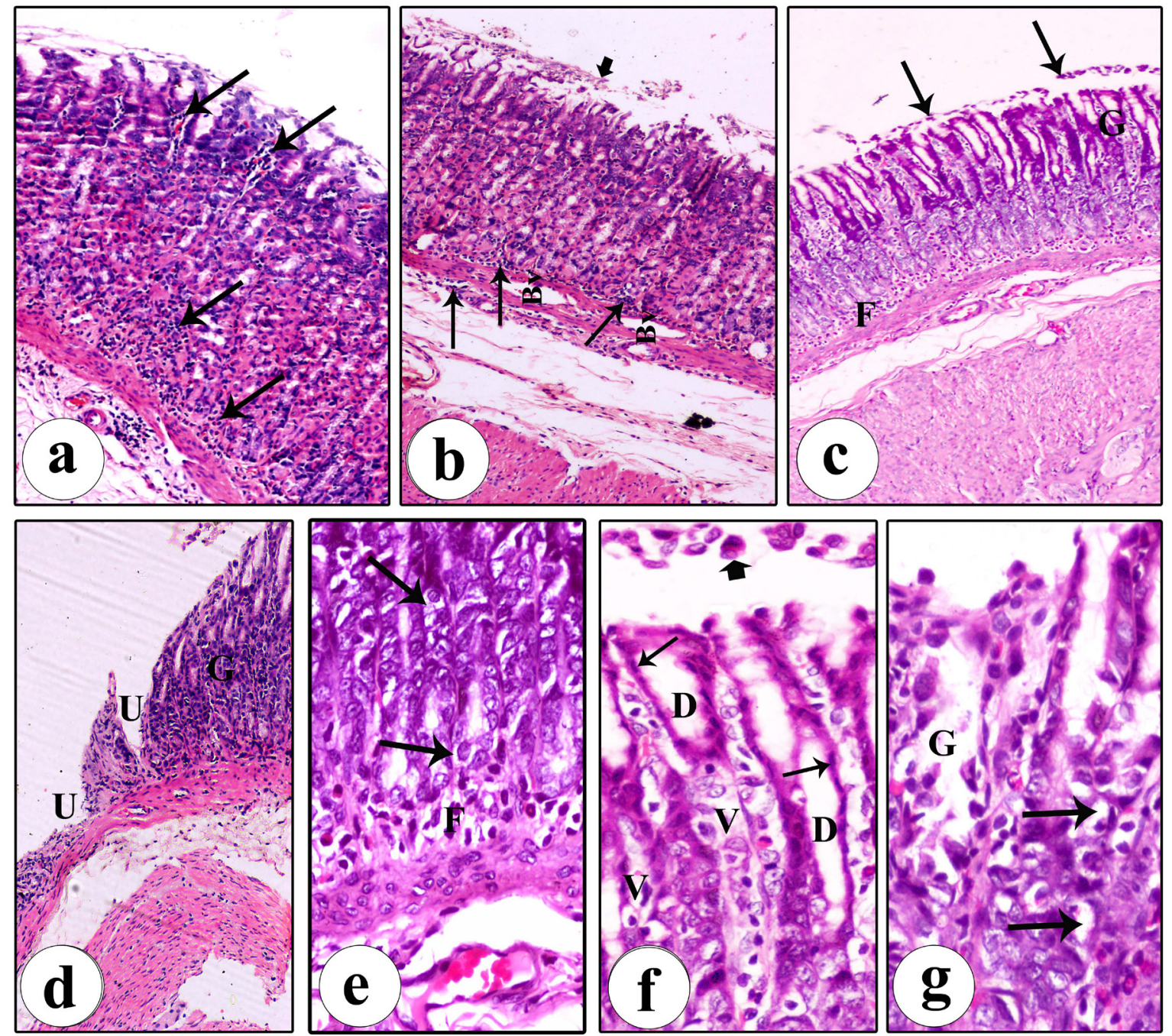

Fig. 2: Light micrographs of the fundic stomach of TCDD-treated rat showing a) dispersed inflammatory cells (arrows) b) dilated blood vessels (Bv), mononuclear cell infiltrations (arrows) and desquamated surface mucosal cells (thick arrow) c) inflammatory cells (F) and atrophic disorganized fundic glands (G). Note the desquamated surface mucosal cells (arrows) d) areas of gastric ulcer (U) and many irregular glands (G) with pyknotic nuclei. e) The basal part of fundic glands showing inflammatory cells (F) in the lamina propria and cytoplasmic vacuolation in many glandular cells (arrows). f) The apical part of fundic glands showing dilated gastric glands (D) lined by flattened epithelial cells (arrows), desquamation of epithelial cells into the lumen (thick arrow) and many glandular cells with vacuolated cytoplasm (V) g) distortion of the gastric glands (G) and vacuolation in many glandular cells (arrows). (H\&E, a,b,c,d X 100 , $\mathrm{e}, \mathrm{f}, \mathrm{g} \times 400)$ 

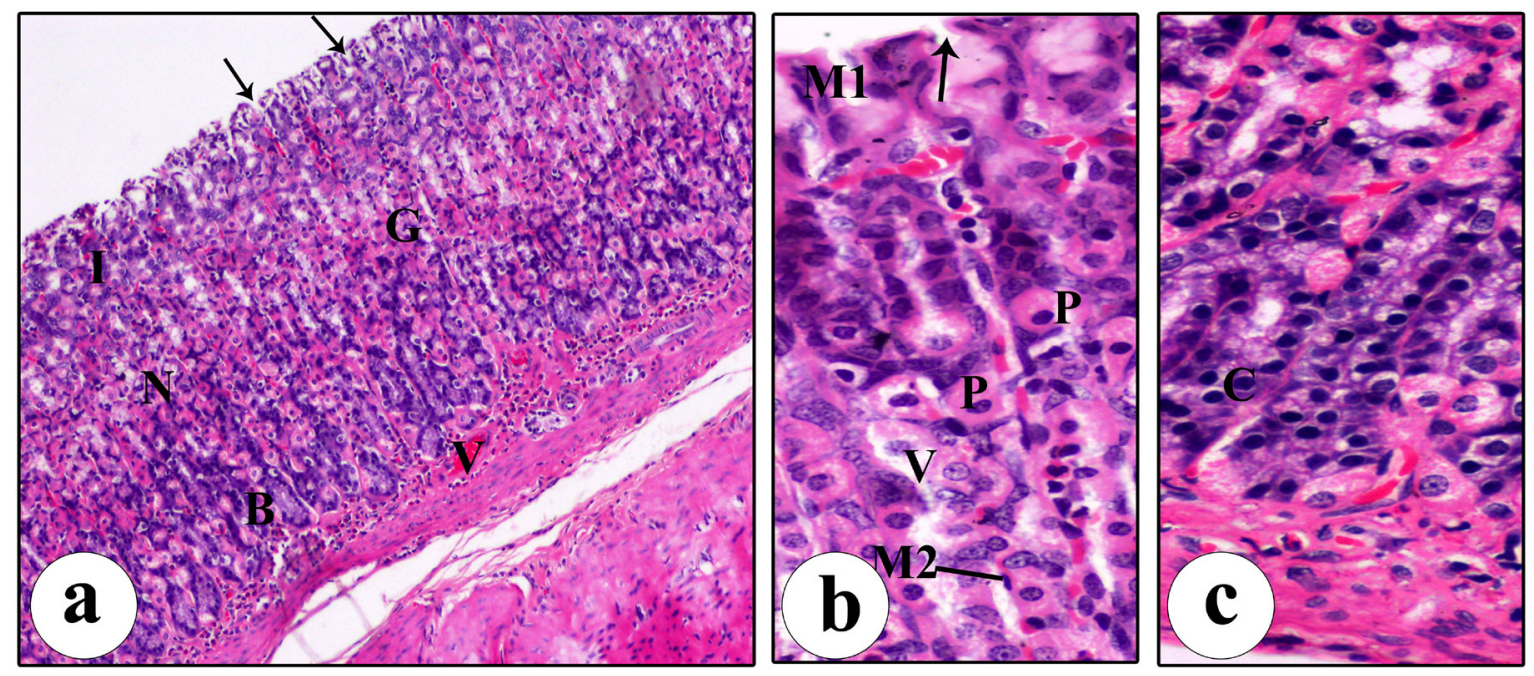

Fig. 3: Light micrographs of the fundic stomach from TCDD and OLE-treated rat showing a) long, packed and regular glands (G) formed of isthmus (I), neck (N) and base (B). Note the relatively preserved gastric pits (arrows) and blood vessels (V) with relatively normal size. b): The apical part of the fundic glands showing relatively preserved mucosal cells and gastric pits (arrow). Note the nearly normal parietal cells (P), surface mucous cells (M1), and mucous neck cells (M2). Some parietal cells appeared with vacuolated cytoplasm (V). c): The basal part of the fundic glands showing nearly normal chief cells (C) with basal nuclei and basophilic cytoplasm. (H\&E a X 100, b, c X 400)
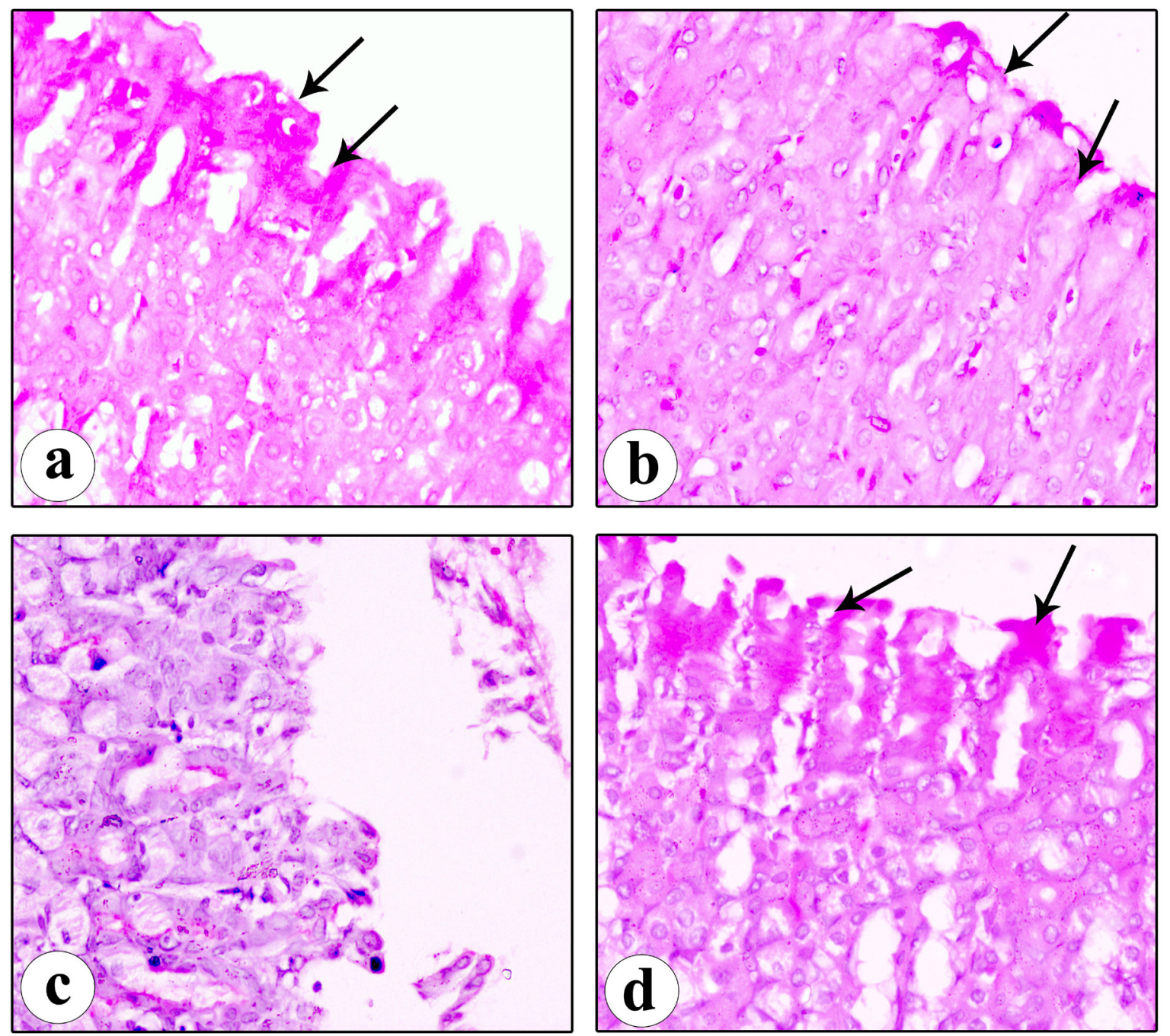

Fig. 4: Light micrographs of the fundic mucosa of a) control rat b) OLE control rat showing strong PAS positive reaction in the surface cells of the mucosa and spread down to the gastric pits (arrows). c) TCDD-treated rat showing weak PAS positive reaction. d) TCDD and OLE-treated rat showing a moderately normal PAS positive reactivity on the mucosal surface cells and extend down into the gastric pits (arrows). (PAS, X 400) 

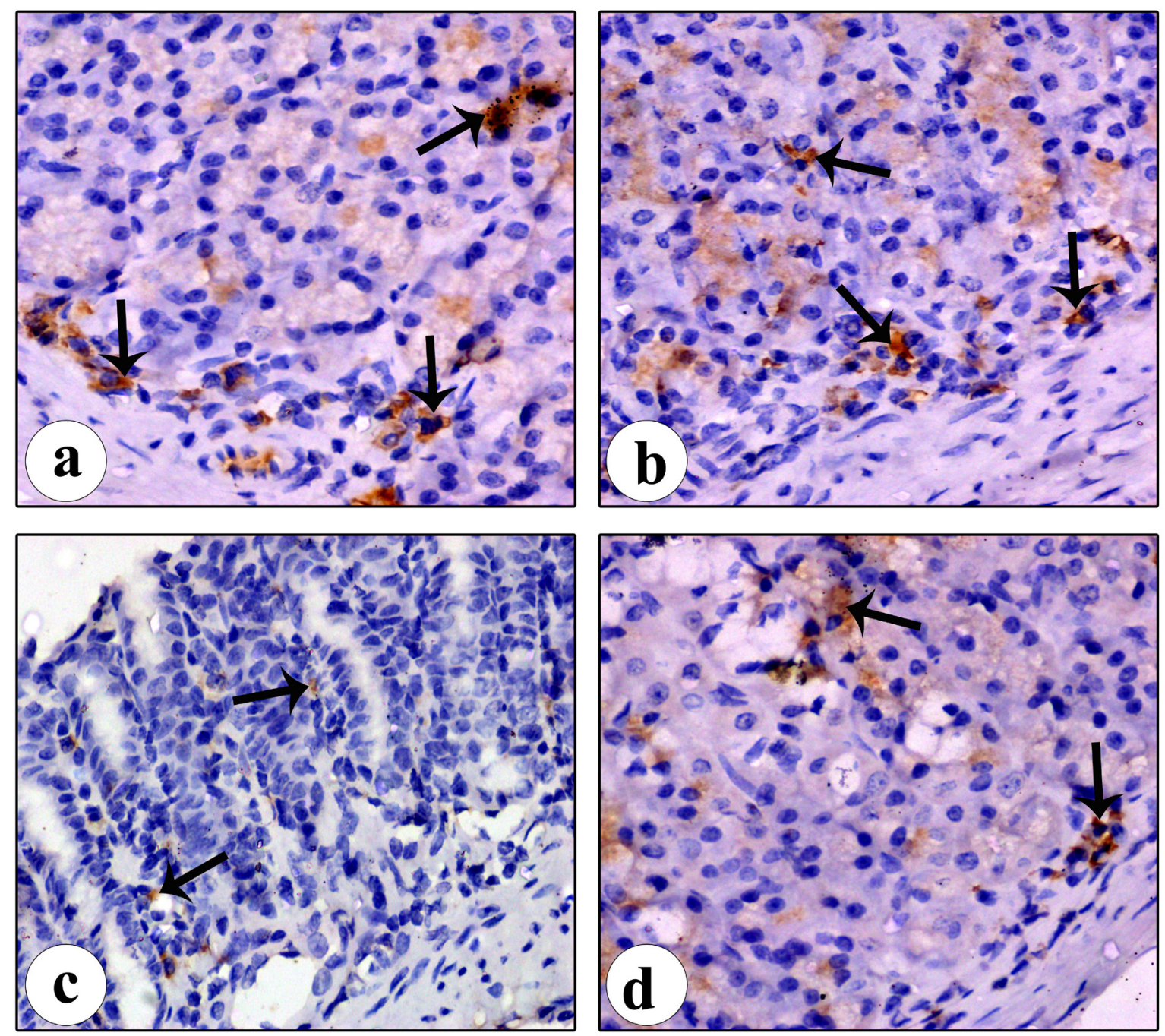

Fig. 5: Light micrographs of the fundic mucosa of a) control rat b) OLE control rat showing strong brown positive chromogranin A immunoreactions in the cytoplasm of fundic glandular cells (arrows). c) TCDD-treated rat showing weak chromogranin A immunoreaction in fundic glandular cells (arrows). d) TCDD and OLE-treated group showing moderate brown chromogranin A immunoreactions in glandular cells (arrows). (Chromogranin A, X 400) 

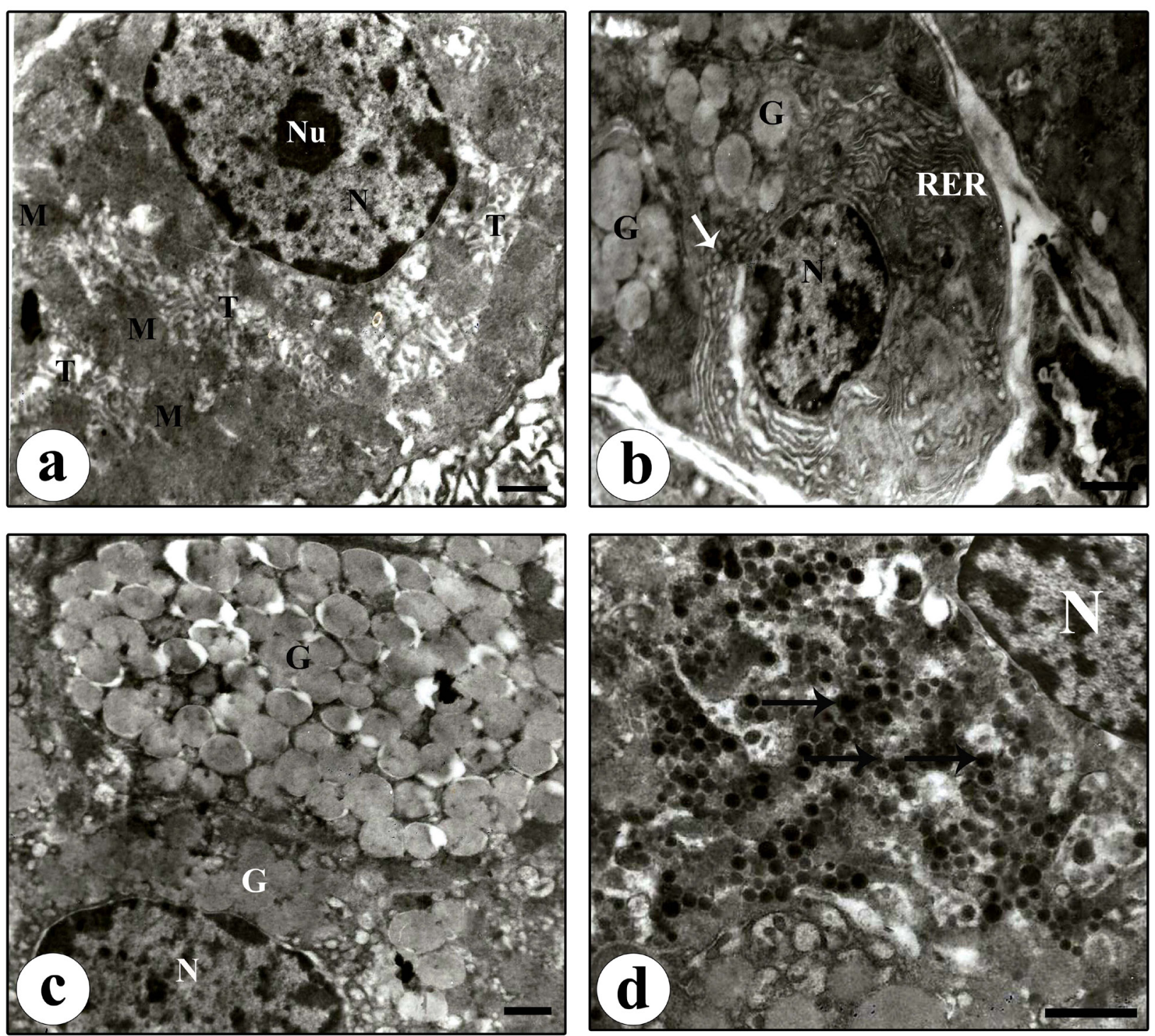

Fig. 6: Electron micrographs of fundic mucosal cells of control rat showing a) a parietal cell with rounded vesicular euchromatic nucleus (N), prominent nucleolus $(\mathrm{Nu})$, and intact tubulovesicular system $(\mathrm{T})$. Note various mitochondria $(\mathrm{M})$ were distributed in the cytoplasm. b) A chief cell with euchromatic nucleus (N), parallel cisterns of rough endoplasmic reticulum (RER), well developed Golgi apparatus (arrow), and variable-sized electron lucent zymogen granules $(\mathrm{G})$ at the apical part of the cell. c) A mucous cell with many electron lucent mucous granules $(\mathrm{G})$ and euchromatic nucleus (N). d) An enteroendocrine cell with small electron dense secretory granules (arrows) at the basal part, and large euchromatic nucleus. TEM: X 6000, Scale bar $=1 \mu \mathrm{m}$ 

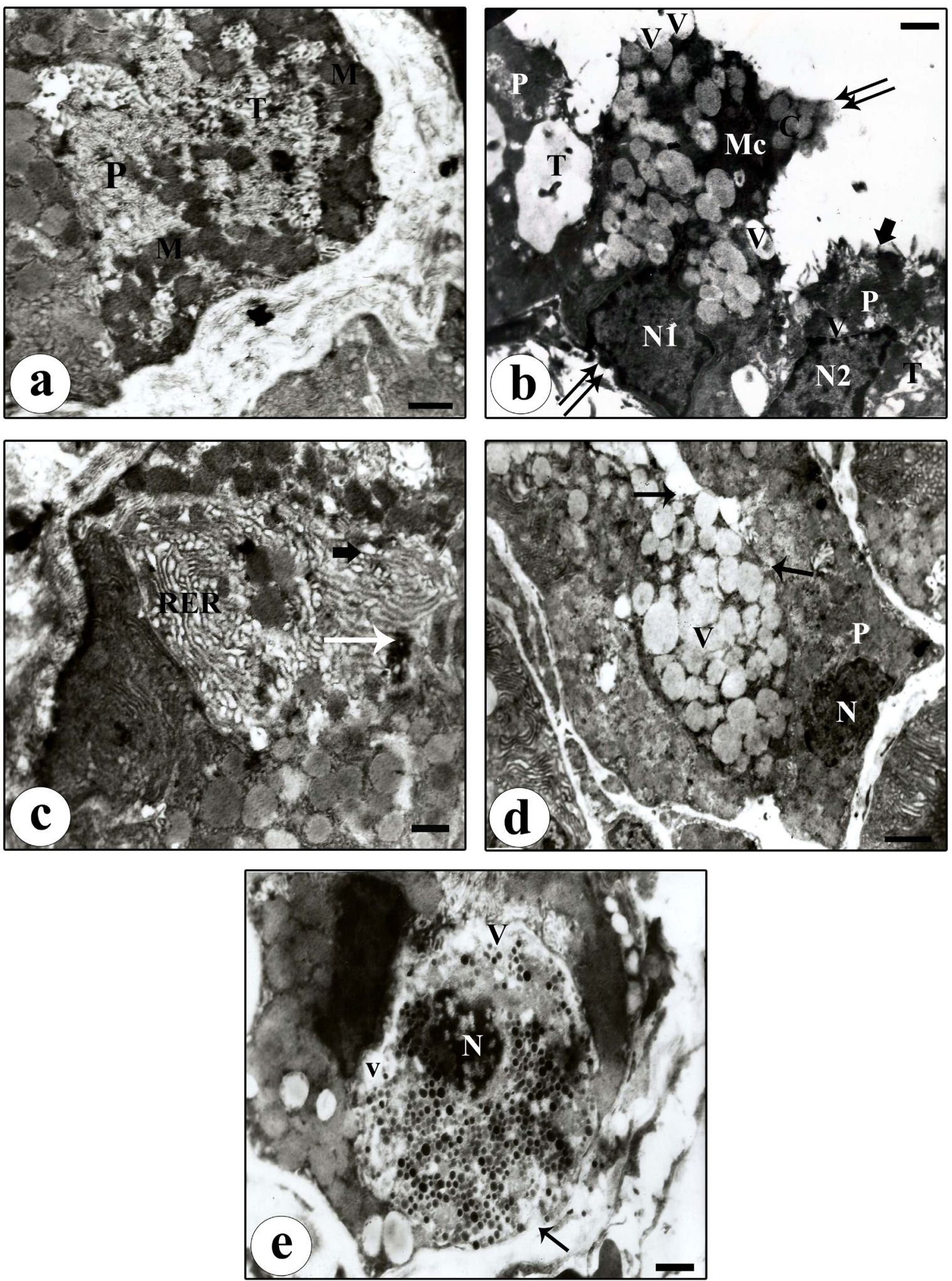

Fig. 7: Electron micrographs of fundic mucosal cells of TCDD-treated rat showing a) a highly degenerated parietal cell (P) having dilated tubulovesicular system (T) and few dense mitochondria (M). b) A mucous cell (Mc) with some empty cytoplasmic vesicles (V), altered cell membranes (double arrows), and nucleus with marginal condensation of heterochromatin (N1). Note two parietal cells (P) with altered cell membrane (thick arrow), vacuolated cytoplasm (V), dilated tubulovesicular system (T), and nucleus with marginal condensation of heterochromatin (N2). c) A chief cell with dilated rough endoplasmic reticulum (RER) and Golgi saccules (thick arrow) and shrunken condensed nucleus (arrow). d) A mucous cell with several empty and fused vesicles (V) and alteration of the cell surface (arrows). Note a part of a parietal cell (P) with and irregular condensed nucleus (N). e) An enteroendocrine cell with irregular pyknotic nucleus $(\mathrm{N})$, and numerous variable-sized electron dense secretory granules, vacuolated cytoplasm (V) and alteration in the cell membrane (arrow). TEM: a X 5000, b, c, e X 6000, and d X 4000, Scale bar $=1 \mu \mathrm{m}$ 

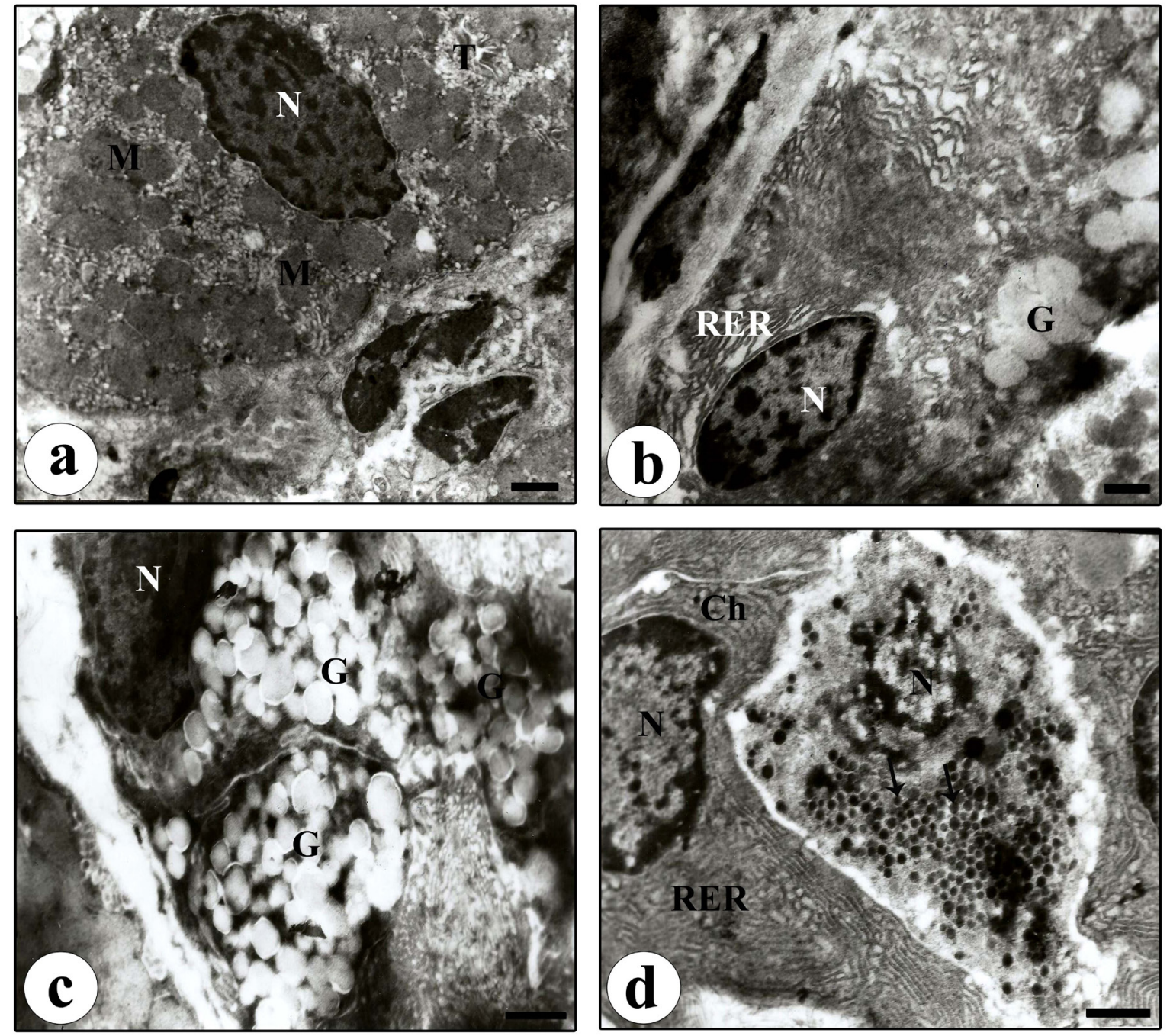

Fig. 8: Electron micrographs of fundic mucosal cells of TCDD and OLE-treated rat showing a) apparently normal parietal cell with euchromatic nucleus $(\mathrm{N})$, various mitochondria $(\mathrm{M})$, and tubulovesicular system $(\mathrm{T})$. b) A chief cell with regular euchromatic nucleus (N), slightly dilated rough endoplasmic reticulum (RER) and electron lucent secretory granules $(\mathrm{G})$. c) A mucous cell with flattened nucleus $(\mathrm{N})$ and secretory granules with variable density $(\mathrm{G})$. d) An enteroendocrine cell with irregular nucleus $(\mathrm{N})$ and many small electron dense secretory granules (arrows). Note a part of a chief cell (Ch) with euchromatic nucleus and regularly arranged rough endoplasmic reticulum (RER). TEM: a, b X, 6000 and c, d X 7500, Scale bar= $1 \mu \mathrm{m}$

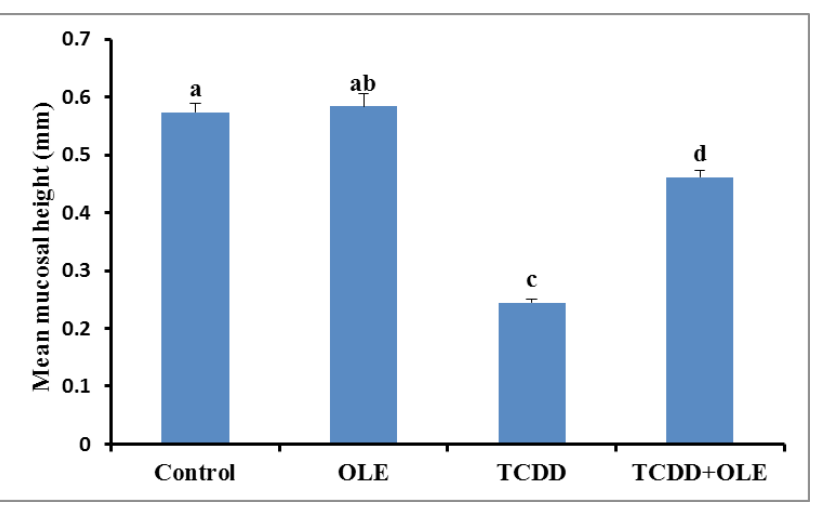

Histogram1: The mean mucosal height in the studied groups.Columns that do not share the same superscript letter are significantly different

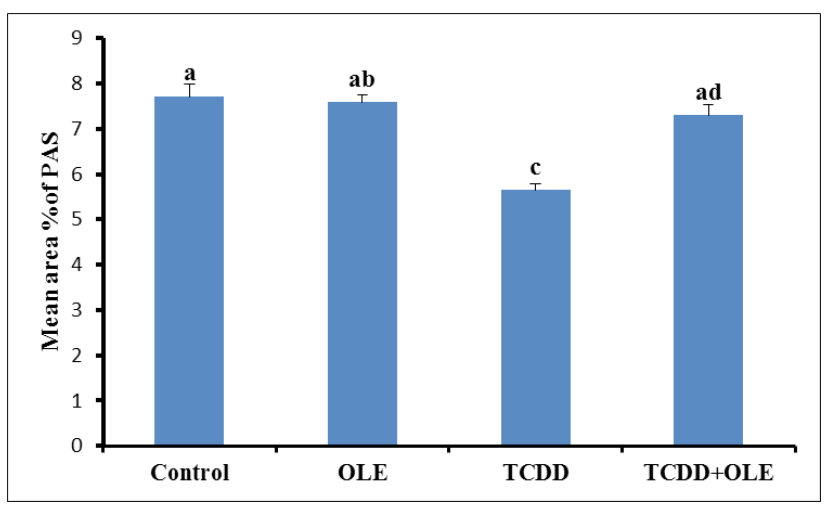

Histogram 2: The mean area percentage (\%) of PAS positive reaction in the studied groups. Columns that do not share the same superscript letter are significantly different. 


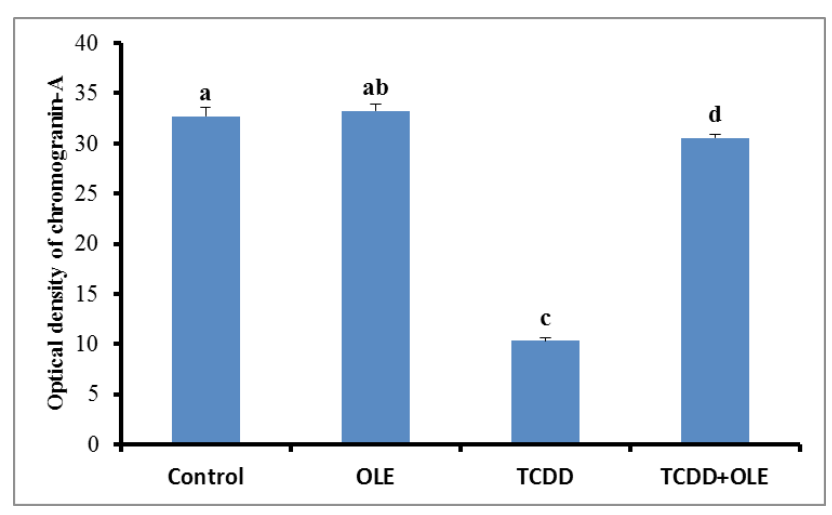

Histogram 3: The mean optical density of Chromogranin A-immunoreactivity in the studied groups. Columns that do not share the same superscript letter are significantly different.

\section{DISCUSSION}

Dioxins are considered as pro-inflammatory environmental factors causing oxidative stress $^{[30]}$. Limited information is available concerning the effect of TCDD on gastric mucosa. In the current study, investigation of the fundic mucosa of TCDD-treated rats showed diverse degrees of histological alterations included; irregular fundic glands, epithelial desquamation, dispersed inflammatory cells, and dilated blood vessels. Most of the examined sections revealed significant decrease in mucosal height with atrophic fundic mucosal areas. These results are in agreement with Amer et al. ${ }^{[31]}$ who reported extensive gastric injuries and alterations in the general construction of gastric glands of TCDD treated rats. In the current study, some glands appeared with lymphocytic aggregation. Previous authors reported that prominent inflammation resulting in degenerative changes in gastric cells and eventually to a conspicuous reduction in the number of glands (atrophic gastritis). Eventually, inflammation may reduce, leaving a thin atrophic mucosa ${ }^{[32]}$. Some authors reported that histamine concentration of the gastric mucosa decreases after gastric mucosal damage, and the histamine content of the gastric lumen increases ${ }^{[33]}$. Histamine causes increased capillary permeability and vasodilatation $^{[33]}$. Gastric mucosa is constantly exposed to harmful agents. Surface epithelium act as a physical barrier among the lumen and the mucosa. Increased epithelial cell loss or decreased cell regeneration may cause mucosal injury ${ }^{[34]}$.

Fundic ulcer was observed in the current work after TCDD administration, with desquamation of surface epithelium. In agreement with the present study, studies on persons exposed to different elements contaminated with TCDD reported significant increases in self-reported ulcers $^{[35]}$. Any disruption of the mucosal barrier leads to gastric ulceration $^{[36]}$. Therefore, the gastric ulcer induced by TCDD may be due to the disturbance of mucosal barrier.

Mucous is composed chiefly of mucins and inorganic salts suspended in water. Mucins are glycoproteins, their carbohydrate components is deeply stained with PAS. In the current study, fundic mucosal cells of TCDD-treated rats showed decreased PAS positive reaction. The present morphometric and ultrastructural studies confirmed this result as the mean area percentage (\%) of the PAS positive reaction was significantly decreased and many cytoplasmic vesicles of the mucous secreting cells appeared empty. The present results are in agreement with other researches ${ }^{[37,38]}$. The authors attributed the decrease in PAS positive reaction to excessive oxidative stress or to the detrimental effect of the ulcerogenic agents on the mucus cells. It has been recorded that mucus secretion had a vital role in the gastro-protection since the mucus had an antioxidant property and protected the mucosa from oxygen radicals ${ }^{[39]}$.

Some of the opposing effects related to dioxin exposure may be mediated by changes in endocrine function ${ }^{[40]}$. Chromogranin is an acidic glycoprotein has a role in hormone and neuropeptide secretion in neuroendocrine cells. Chromogranin-A is the main member of the granin family. It is a common indicator for gut endocrine cells ${ }^{[41]}$. Neuronal transmitters and neuropeptides facilitate and regulate the stomach function. They are secreted by set of neuroendocrine cells and have a role in acid secretion, motility regulation, hormonal release, local blood flow and mucosal defense mechanisms ${ }^{[42]}$. So, Chromogranin A manifestation was examined immunohistochemically in the present study. It revealed a weak positive immuoreaction in TCDD-treated group demonstrating damage of these cells in injured mucosa. The morphometric study confirmed this result as the mean optical density of chromogranin A expression was significantly decreased in comparison to the control subgroups. Such result was in accordance with Biswas et al. ${ }^{[43]}$. The authors indicated that, augmented microvascular damage leads to ischemia which causes necrosis of mucosal cells. Low oxygen pressure and the consequent reduction of ATP formation, disturb sodium potassium pump resulting in inflow of sodium into the cell and osmotic gain of water. Simultaneously, the intracellular calcium increases through inflow from the extracellular fluid and its discharge from the intracellular stores. This triggers endonuclease, protease, and phospholipases which lead to cellular injury ${ }^{[44]}$. Several studies stated that TCDD leads to vascular dysfunction ${ }^{[45,46]}$.

The present electron microscopic study showed deteriorating changes in fundic mucosal cells of rats treated with TCDD. Parietal cells, chief cells, mucous cells and enteroendorine cells appeared highly affected. The parietal cells seemed vacuolated with pyknotic nuclei, few mitochondria, and dilated microvascular structures. These results are in agreement with the results of Amer et al. ${ }^{[31]}$ who reported degeneration of the parietal cells, chief cells and enteroendocrine cells following TCDD administration to rats.

In the present study, apoptotic signs were observed in many cells of the gastric glands after administration of TCDD. The nuclei were pyknotic and shrunken, with condensation of their heterochromatin. TCDD induced apoptosis by arresting the cells at G1 phase of the cell cycle or through initiation of oxidative stress ${ }^{[47]}$. Khattab ${ }^{[48]}$ reported that ethylene glycol treated rats showed damage of mitochondria, 
endoplasmic reticulum and Golgi apparatus in the peptic and parietal cells. Mitochondrial alterations could be clarified by formation of free radicals leading to lipid peroxidation and oxidative stress. The free radicals bind to mitochondrial DNA, leading to impaired mitochondrial structure ${ }^{[49]}$.

Endoplasmic reticulum stress has been linked with the pathogenicity of gastritis through apoptotic pathways ${ }^{[50]}$. Furthermore, oxidative stress induced gastric illnesses play an important role in gastric mucosal cell damage, mainly from exogenous stimuli ${ }^{[51]}$. The chief cells, in the current study, appeared with dilated rough endoplasmic reticulum (RER). The RER is a factory for synthesis and folding of protein, after that the proteins are transported to the Golgi apparatus. Some authors reported that TCDD-induced ER stress and apoptosis ${ }^{[52]}$. ER stress lead to up regulation of reactive oxygen species (ROS) generation ${ }^{[53]}$.

The precise mechanism of TCDD affects stomach tissue is not known. Some studies reported that TCDD induce oxidative effect on other tissues such as intestine, heart, liver and testis ${ }^{[7,54]}$. Another mechanism is the motivation of cyclooxygenase (COX)-2 (an enzyme accountable for inflammation), which generates prostaglandins synthesis. In addition, the effects of the aryl hydrocarbon receptor indirectly contribute to the augmented synthesis of monooxygenase (CYP1), which increases the inflammatory processes $^{[55]}$.

Previous data has pointed to the role of herbal drugs in the treatment and protection of gastric and duodenal ulcers. These herbs could be applied as medications supplementing or improving the action of synthetic drugs ${ }^{[56]}$. In the current study, the fundic mucosa of TCDD and OLE group showed an improvement in the histological architecture and ultrastructure of fundic glands. The gastric mucosal height and PAS-positive reaction were significantly increased in comparison to that of TCDD group. The increased PAS positive secretion may be arisen from the reduced free radical production by OLE. In agreement with the present results, the improved effect of OLE on the mucus secretion was demonstrated in indomethacin-induced gastric ulcer rat model ${ }^{[57]}$.

The increase in chromogranin A immunostaining cells after OLE supplementation reveals that OLE relatively preserved the gastric endocrine cells to its normal level. The present findings are in accordance with Mazzawi et $a l .{ }^{[41]}$ who reported increased cellular density of gastric chromogranin A after modifications to diets of patients suffered from irritable bowel syndrome.

Phytochemical analysis of OLE performed by some authors showed a high content of oleuropein (almost $20 \%$ ) and other constituents which are important for gastroprotection (apigenine-7-O-glucoside, luteoline-7O-glucoside, quercetin and caffeic acid) as well as a low concentration of tannins ${ }^{[58]}$. The gastroprotective activity of OLE might be related to the ability of its constituents to scavenge ROS produced by TCDD. Its anti-ulcer effect may be resulted from its ability to preserve the cell membrane integrity, by protecting the gastric mucosa from oxidative damage, and its ability to reinforce mucosal barrier which is the first line of protection against ulcerogenic agents and to the accurate blood flow ${ }^{[59]}$. In agreement with the present results, the protective effect of OLE pretreatment in gastric ulcer models were established in the histological structure of stomach in previous studies ${ }^{[58,59]}$. Some authors reported that OLE reduces the COX-2 and inflammatory injury in colonic samples from patients suffered from ulcerative colitis ${ }^{[0]}$. Moreover some flavones, flavonols and anthraquinones revealed obvious inhibitory activities on the in vitro motivation of aryl hydrocarbon induced by $\mathrm{TCDD}^{[61]}$.

\section{CONCLUSION}

The current study indicates that TCDD exposure at a dose of $100 \mu \mathrm{g} / \mathrm{kg}$ body weight /day leads to histopathological and ultrastructural changes in gastric mucosa of male albino rats. Moreover, OLE $(0.5 \mathrm{~g} / \mathrm{kg}$ body weight $/$ day $)$ most likely has prevented the toxic effect of TCDD on histological and ultrastructual levels. Thus, the present study showed that OLE might be useful for the inhibition and treatment of TCDD induced gastric toxicity, and might also be valuable in the supportive care of persons subjected to TCDD.

\section{CONFLICTS OF INTEREST}

There are no conflicts of interest.

\section{REFERENCES}

1. Verreault J, Helgason LB, Gabrielsen GW, Dam $\mathrm{M}$, Braune BM. Contrasting retinoid and thyroid hormone status in differentially-contaminated northern fulmar colonies from the Canadian Arctic, Svalbard and the Faroe Islands. Environ Int. (2013) 52:29-40.

2. Patandin S, Dagnelie PC, Mulder PG, Op deCoul E, van derVeen J E, Weisglas-Kuperus $\mathrm{N}$, and Sauer P J. Dietary exposure to polychlorinated biphenyls and dioxins from infancy until adulthood: A comparison between breast-feeding, toddler, and long-term exposure. Environ. Health Perspect. (1999) 107-45-51.

3. Czepiel J., Biesiada G, Gajda M, Szczepanski W, Szypuea K, Dabrowski Z, and Mach T. The Effect of TCDD Dioxin on the Rat Liver in Biochemical and Histological Assessment. Folia biologica (Kraków). (2010) 58 (1-2):85-90

4. Ciftci O, Duman A S, Turkmen N B, and Asl Taslidere A. Beta-glucan prevents toxic effects of 2,3,7,8-TCDD in terms of oxidative and histopathological damage in heart tissue of rats. Braz. J. Pharm. Sci. (2018) 54 (3):e17674.

5. Guo S, Zhang R, Liu Q, Wan Q, Wang Y, Yu Y, Liu G, Shen Y, Yu Y,and Zhang J. 2,3,7,8-Tetrachlorodibenzo-p-dioxin promotes injury-induced vascular neointima formation in mice. FASEB J. (2019) 33(9):10207-10217. 
6. Ilhan S; Atessahin D, Atessahin A, Mutlu E, Onat E and Sahna E. 2,3,7,8- Tetrachlorodibenzo-pdioxin-induced hypertension: the beneficial effects of melatonin. Toxicology and Industrial Health. (2015) 31 (4): 298-303.

7. Aylward LL, Collins JJ, Bodner KM, Wilken $\mathrm{M}$, Bodnar CM. Elimination rates of dioxin congeners in former chlorophenol workers from Midland, Michigan. Environ Health Perspect. (2013) 121(1):39-45.

8. Bonefeld-Jorgensen EC. Biomonitoring in Greenland: human biomarkers of exposure and effects- short review. Rural Remote Health. (2010) 10 (2):1362.

9. Cakir O., Ozdemir I. The Investigation of Protective Effect of Quercetin in Rats Exposed to Oxidative Stress by 2,3,7,8-Tetrachlorodibenzo-p-Dioxin. Hacettepe Journal of Biology and Chemistry. (2019) 47 (1), 61-66.

10. Schlummer M, Moser G A, and McLachlan M S. Digestive tract absorption of PCDD/Fs, PCBs, and $\mathrm{HCB}$ in humans: mass balances and mechanistic considerations. Toxicol Appl Pharmacol. (1998) 152:128-137.

11. Ishida $\mathrm{T}$, Kan $\mathrm{O} \mathrm{S}$, Mutoh J, Takeda $\mathrm{S}$, Ishii Y, Hashiguchi I, Akamine A and Yamada $\mathrm{H}$. 2,3,7,8-Tetrachlorodibenzo-p-dioxin-induced change in intestinal function and pathology: evidence for the involvement of arylhydrocarbon receptormediated alteration of glucose transportation. Toxicol Appl Pharmacol. (2005) 205:89-97.

12. Park J U, Kang J H, Abdur Rahman M A, Hussain A, Cho J S and Lee Y I. Gastroprotective Effects of Plants Extracts on Gastric Mucosal Injury in Experimental Sprague-Dawley Rats. BioMed Research International (2019) (1):1-11.

13. Duh P D. Antioxidant activity of burdock (Arctium lappa Linne): Its scavenging effect on free radical and active oxygen. J Am Oil Chemist's Soc. (1998) 75: 455- 465.

14. Lai L S, Chou S T, and Chao W W. Studies on the antioxidative activities of Hsian-tsao (Mesona procumbens Hemsl) leaf gum. J Agric Food Chem. (2001) 49(2):963-968.

15. Žuntaret I, Predrag Putnik P, Kovǎcevi'c D B, Nutrizio M, Šupljika F, Poljanec A, Dubrovi'c I, Barba F J, and Jambrak A R. Phenolic and Antioxidant Analysis of Olive Leaves Extracts (Olea europaea L.) Obtained by High Voltage Electrical Discharges (HVED). Foods. (2019) 8, 248; doi:10.3390/foods8070248.

16. Lee O, Lee B, Lee J, Lee, H, Son J, Park C, Shetty K, Kim Y. Assessment of phenolics- enriched extract and fractions of olive leaves and their antioxidant activities. Bioresource Technol. (2009) 100 (23):6107-6113.

17. Lee O H, Lee B Y. Antioxidant and antimicrobial activities of individual and combined phenolics in Olea europaea leaf extract. Bioresour Technol. (2010) 101(10):3751-3754.

18. Omar S H. Cardio protective and neuroprotective roles of oleuropein in olive. Saudi Pharm J. (2010) 18 (3):111- 121.

19. Al-Quraishy S, Othman M S, Dkhil M A, and Abdel Moneim, A E. Olive (Olea europaea) leaf methanolic extract prevents $\mathrm{HCl} /$ ethanol-induced gastritis in rats by attenuating inflammation and augmenting antioxidant enzyme activities. Biomed. Pharmacother. (2017) 91:338-349.

20. Sarbishegi M, Charkhat Gorgich E, Ozra Khajavi O. Olive Leaves Extract Improved Sperm Quality and Antioxidant Status in the Testis of Rat Exposed to Rotenone. Nephrourol Mon. (2017) 9 (3):e47127.

21. Vizza D. Lupinacci S, Toteda G, Puoci, F, Ortensia I P, De Bartolo A, Lofaro D, Scrivano L, Bonofiglio R, Russa A L, Bonofiglio M, Perri A. An olive leaf extract rich in polyphenols promotes apoptosis in cervical cancer cells by upregulating p21cip/wafl gene expression. Nutr. Cancer. (2019); 71, 320-333.

22. Abaza L, Talorete T P, Yamada P, Kurita Y, Zarrouk $\mathrm{M}$, and Isoda H. Induction of growth inhibition and differentiation of human leukemia HL-60 cells by a Tunisian gerboui olive leaf extract. Bioscience, Biotechnology, and Biochemistry. (2007) 71(5):1306-1312.

23. Eidi A, Eidi M, and Darzi R. Antidiabetic effect of Olea Europaea Lin normal and diabetic rats. Phytotherapy Research: PTR. (2009) 23(3):347-350.

24. Theobald H M, Ingall G B, Mably T A and Peterson $\mathrm{R}$ E. Response of the antral mucosa of the rat stomach to 2,3,7,8-tetrachlorodibenzo-p-dioxin. Toxicol Appl Pharmacol. (1991) 108:167-179.

25. Bancroft J D and Layton C. The hematoxylin and eosin, connective mesenchymal tissues with their stains In: Suvarna SK, Layton C and Bancroft JD, editors. Bancroft's Theory and practice of histological techniques. 7th edition. Churchill Livingstone: Philadelphia. (2013) 173-212 and 215-238.

26. Kiernan JA. Theory and practice in histological and histochemical methods. 3rd ed. Butterworth: Oxford (2000) . pp. 267-281, 390-418.

27. Glauert A M and Lewis P R. Biological specimen preparation for transmission electron microscopy. 1st ed. London: Portland Press (1998). 
28. Reynolds E S. The use of lead citrate at high $\mathrm{pH}$ as an electron-opaque stain in electron microscopy. The Journal of Cell Biology. (1963) 17: 208-212.

29. IBM Corp. Released. IBM SPSS Statistics for Windows, Version 20.0. Armonk, N.Y.: IBM Corp (2011).

30. Aly $\mathrm{H}$ A and Domenech O. Cytotoxicity and mitochondrial dysfunction of 2,3,7,8-tetrachlorodibenzo-p-dioxin (TCDD) in isolated rat hepatocytes. Toxicol Lett. (2009) 191: 79-87.

31. Amer M G, Mohamed D A, and Karam $\mathrm{R}$ A. Protective role of curcumin against 2,3,7,8-tetrachlorodibenzodioxin-induced histological and biochemical changes in fundic mucosa of the adult rat stomach. The Egyptian Journal of Histology. (2013) 36:13-27.

32. Rubin R and Strayer D S. Rubin's pathology. $5^{\text {th }}$ ed. Philadelphia: Lippincott Williams and Wilkins; (2008).

33. Zhao W, Zhu F, Shen W, Fu A, Zheng L, Yan Z, Zhao L and Fu G. Protective effects of DIDS against ethanol-induced gastric mucosal injury in rats. Acta Biochim Biophys Sin (Shanghai). (2009) 41:301-308.

34. Bashandy M and Seleem H. Effect of hunger and thirst stress on the fundic mucosa of the stomach of adult female albino rats (Histological, histochemical and immunohistochemical study). Journal of American Science. (2014) 10: 264-273.

35. Bond G G, McLaren E A, Lipps T E, and Cook R R. Update of mortality among chemical workers with potential exposure to the higher chlorinated dioxins. J Occup Med. (1989) 31:121-123.

36. Saeki T, Ohno T, Boku K, Saigenji K, Katori M and Majima M. Mechanism of prevention by capsaicin of ethanol induced gastric mucosal injury-a study in the rat using intravital microscopy. Aliment. Pharmacol. Ther. (2000) 14 (1): 135-144.

37. AL-Wajeeh N S, Hajrezaie M, Al-Henhena N, Kamran S, Bagheri E, Zahedifard M, Saremi K, Noor S M, Ali H M, Abdulla M A. The antiulcer effect of Cibotium barometz leaves in rats with experimentally induced acute gastric ulcer. Design, Development and Therapy. (2017) 11:995-1009.

38. El-Azab N E, Mansy A E, El-Mahalaway M A, and Sabry, D. Comparative study of the therapeutic effect of pomegranate alone or in combination with bone marrow mesenchymal stem cells on experimentally induced gastric ulcer in adult male rats: A histological and immunohistochemical study. The Egyptian journal of histology. (2018) 41(2):150-166.
39. Tarique M, Siddiqui H H, Khushtar M, Rahman M A. Protective effect of hydro-alcoholic extract of Ruta graveolens Linn. leaves on indomethacin and pylorus ligation-induced gastric ulcer in rats. J Ayurveda Integr Med. (2016) 7(1):38-43.

40. Diamanti-Kandarakis E, Bourguignon J-P, Giudice LC, and Hauser R. Endocrine disrupting chemicals: an endocrine society scientific statement. Endocrine Reviews. (2009) 30: 293-342.

41. Mazzawi T, Gundersen D, Hausken T, EL Salhy M. Increased gastric chromogranin A cell density following changes to diets of patients with irritable bowel syndrome. Molecular Medicine reports. (2014) 10: 2322-2326.

42. El-Salhy M, Gilja OH, Hausken T. Chromgranin A cells in stomach of patients with sporadic irritable bowel syndrome. Molecular Medicine Reports. (2014) 10:1753-1757.

43. Biswas K, Bandyopadhyay U, Chattopadhyay I, Varadaraj A, Ali E, and Banerjee R. A novel antioxidant and antiapoptotic role of omeprazole to block gastric ulcer through scavenging of hydroxyl radical. J Biol Chem. (2003) 278: 10993-11001.

44. Sun Y, Chen X, Liu J, Cheng X, Wang X, Kong Q, Li H. Differential caspase-3 expression in non-cancerous, pre-malignant and cancer tissues of stomach and its clinical implication. Cancer Detect Prev. (2006) 30: 168- 173.

45. Kopf PG, Walker MK. 2,3,7,8-Tetrachlorodibenzopdioxin increases reactive oxygen species production in human endothelial cells via induction of cytochrome P4501A1. Toxicology and Applied Pharmacology. (2010) 245: 91-99.

46. Ciftci $\mathrm{O}$ and Ozdemir I. Protective effects of quercetin and chrysin against 2,3,7,8 tetrachlorodibenzo-p-dioxin (TCDD) induced oxidative stress, body wasting and altered cytokine productions in rats. Immunopharmacology and Immunotoxicology. (2011) 33(3): 504-508.

47. Güler $G$ and Çelik A. 2,3,7,8 Tetrachlorodibenzo-p-dioxin: Genotoxicity and Oxidative Damage Potential in Human Peripheral Blood Lymphocytes. J Carciong Mutagen., (2016) 7 (4). doi:10.4172/2157-2518.1000274.

48. Khattab F K I. Histological and ultrastructural studies on the gastric mucosa of rat after treatment with ethylene glycol. Aust. J. Basic Appl. Sci. (2007) 1(3): 157-168.

49. Lakhani S R, Finlayson C J, Dilly S A, and Gandhi M. Basic pathology: An introduction to the mechanisms of disease. (2011). Crc Press.

50. Lou LX, Geng B, Yu F, Zhang J, Pan CS, Chen L, Qi YF, Ke Y, Wang X, and Tang CS: Endoplasmic 
reticulum stress response is involved in the pathogenesis of stress induced gastric lesions in rats. Life Sci. (2006) 79: 18561864.

51. Suzuki H, Nishizawa T, Tsugawa H, Mogami S and Hibi T. Roles of oxidative stress in stomach disorders. J Clin Biochem Nutr. (2012) 50: 3539.

52. Duan Z, Zhao J, Fan X, Tang C, Liang L, Nie X, Liu J, Wu Q, Xu G. The PERK-eIF2 $\alpha$ signaling pathway is involved in TCDD-induced ER stress in PC12 cells. Neurotoxicolog (2014) 44:149-159.

53. Malhotra JD, Miao H, Zhang K, Wolfson A, Pennathur S, Pipe SW and Kaufman RJ: Antioxidants reduce endoplasmic reticulum stress and improve protein secretion. Proc Natl Acad Sci USA 105: 1852518530 (2008).

54. Gilroy DW, Tomlinson A, Willoughby DA. Differential effects of inhibitors of cyclooxygenase (cyclooxygenase 1 and cyclooxygenase 2) in acute inflammation. Eur $\mathrm{J}$ Pharmacol. (1998) 355: 211-217.

55. Ciftci O, Vardi N, and Ozdemir I. Effects of quercetin and chrysin on 2,3,7,8-tetrachlorodibenzo-p-dioxin induced hepatotoxicity in rats. Environ Toxicol. (2013) 28 (3):146-154.

56. Ayala G, Escobedo-Hinojosa W I, de la CruzHerrera C F and Romero, I. Exploring alternative treatments for Helicobacter pylori infection. World J Gastroenterol. (2014) ; 20 (6), 1450-1469.
57. Koc K, Cerig S, Ucar S, Colak S, Bakir M, Erol H S, Yildirim S, Mirkhalil Hosseinigouzdagani M, Ozek N S, Aysin F, Kocpinar E F, n Budak H, and Geyikoglu F. Gastroprotective effects of oleuropein and thymol on indomethacin-induced gastric ulcer in Sprague Dawley rats. Drug and Chemical Toxicology. (2018) 14:1-13.

58. Dekanski D, Janićijević-Hudomal S, Tadić V, Markovicć G, Arsić I and Mitrović D. Phytochemical analysis and gastroprotective activity of an olive leaf extract. J Serb Chem Soc. (2009) 74:367-377.

59. Chauhan A K and Kang S C. Therapeutic potential and mechanism of thymol action against ethanol-induced gastric mucosal injury in rat model. Alcohol. (2015) 49 (7): 739-745.

60. Larussa T, Oliverio M, Suraci E , Greco M , Placida R , Gervasi S , Marasco R , Imeneo M , Paolino D, Tucci L, Gulletta E , Fresta M , Procopio A and Luzza F. Oleuropein Decreases Cyclooxygenase-2 and Interleukin-17 Expression and Attenuates Inflammatory Damage in Colonic Samples from Ulcerative Colitis Patients. Nutrients (2017) 9 (391): 1-11.

61. Amakura Y, Tsutsumi T, Sasaki K, Nakamura $\mathrm{M}$, Yoshida T. Influence of food polyphenols on aryl hydrocarbon receptor-signaling pathway estimated by in vitro bioassay. Phytochemistry 69 (18):3117-3130. 
الملخص العربى

\section{التأثثر الوقائي لمستخلص أوراق الزيتون ضد ثلف الغثاء المخاطي لقعر المعدة المستحث بمادة ب و بو Vو ^ رباعي كلورودي بنزو ديوكسين فى ذكور الجرذان البيضاء البالغة دراسة بالميكروسكوب الضوئى والالكترونى}

\section{مروة صلاح}

\section{قسم علم الحيوان- كلية العلوم- جامعة بنى سويف}

المقدمة : تعتبر مادة זو گو لو 1 نتر ا كلورو ديبنزوديوكسين من أكثر المواد الكيميائية الصناعية السامة الموجودة في البيئة. يرتبط التعرض لـهذه الماده بتلف في المعدة. من ناحية أخري، يستخدم مستخلص أور اق الزيتون في الأدوية وله أثنار علاجية مفيدة. الهرف: تقدير التأثير الوقائي لمستخلص أوراق الزيتون على تلف بطانة قعر المعدة المستحث بمادة تتر ا كلورو ديينزوديوكسين في ذكور الجرذان البيضاء البالغة. مواد وطرق البحث : تم تقسيم سبعون فأر ا من ذكور الفئران البالغة إلى بـ مجمو عات: المجموعة الأولى (المجمو عة

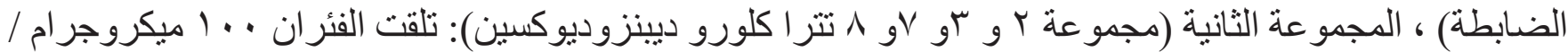

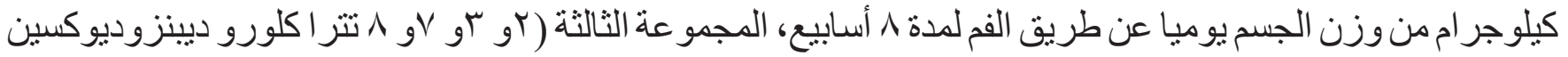

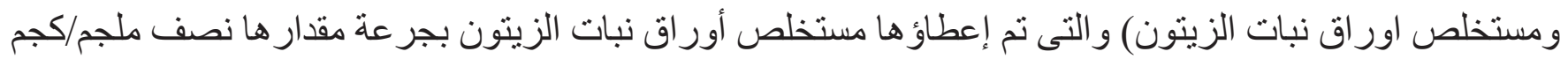

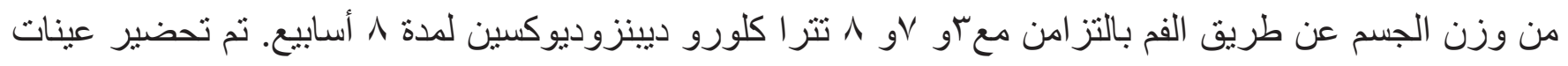
من قعر المعدة وصباغتها بصبغة الهيماتوكسيلين والأيوسين (H\&E) وصبغة حامض شيف الدوري (PAS) وتم

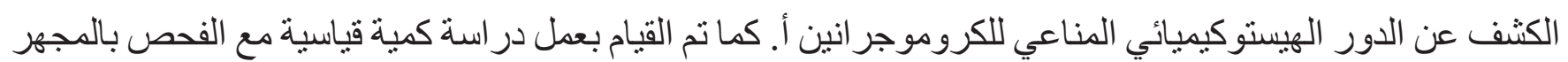
الألكتروني. النتائج: أوضحت النتائج وجود نغير ات فى بطانة المعدة و انفصال خلايا الغشاء المخاطي السطحي، وجود قرح معدية بالإضافة الى تلف في الغدد مع وجود مساحات من الألتهاب الضموري في المعدة والموت المبرمج للخلايا و انخفاض ملحوظ فى كلا من ارتفاع الطبقة المخاطية المبطنة لقعر المعدة، الكروموجر انين أو الاماكن المصبو غة بصبغة ولة حامض شيف الدوري (PAS). أظهرت الدراسات المجهرية الإكترونية التغيرات المتدهورة في الخلايا الجدارية والخلايا الرئيسية و الخلايا المخاطية وخلايا الغدد الصماء المعوية. وفي المقابل أظهر مستخلص أوراق شجرة الزيتون تأثير وقائي ضد التأثثر ات المعدية المحدثة بمادة التتر ا كلورو ديبنزوديوكسين حيث لم يلاحظ معظم التغير ات المحدثة بمادة التثر ا كلورو ديبنزوديوكسين في المجموعة الثالثة. الخلاصة: التتر ا كلورو ديبنزوديوكسين له آثار سامة على البطانة المعدية وان استخدام مستخلص أور اق الزيتون قد قلل من تللك الاثار. ولذلك يمكن استخدام هذا المستخلص لتجنب المضاعفات المعدية المحدثة بهذه المادة. 